\title{
Hand hygiene determinants of informal caregivers in hospitals under Pender's perspective
}

\author{
Determinantes de higienização das mãos de cuidadores informais em hospitais sob a perspectiva de Pender
}

Determinantes de higienización de manos de cuidadores informales en hospitales bajo la perspectiva de Pender

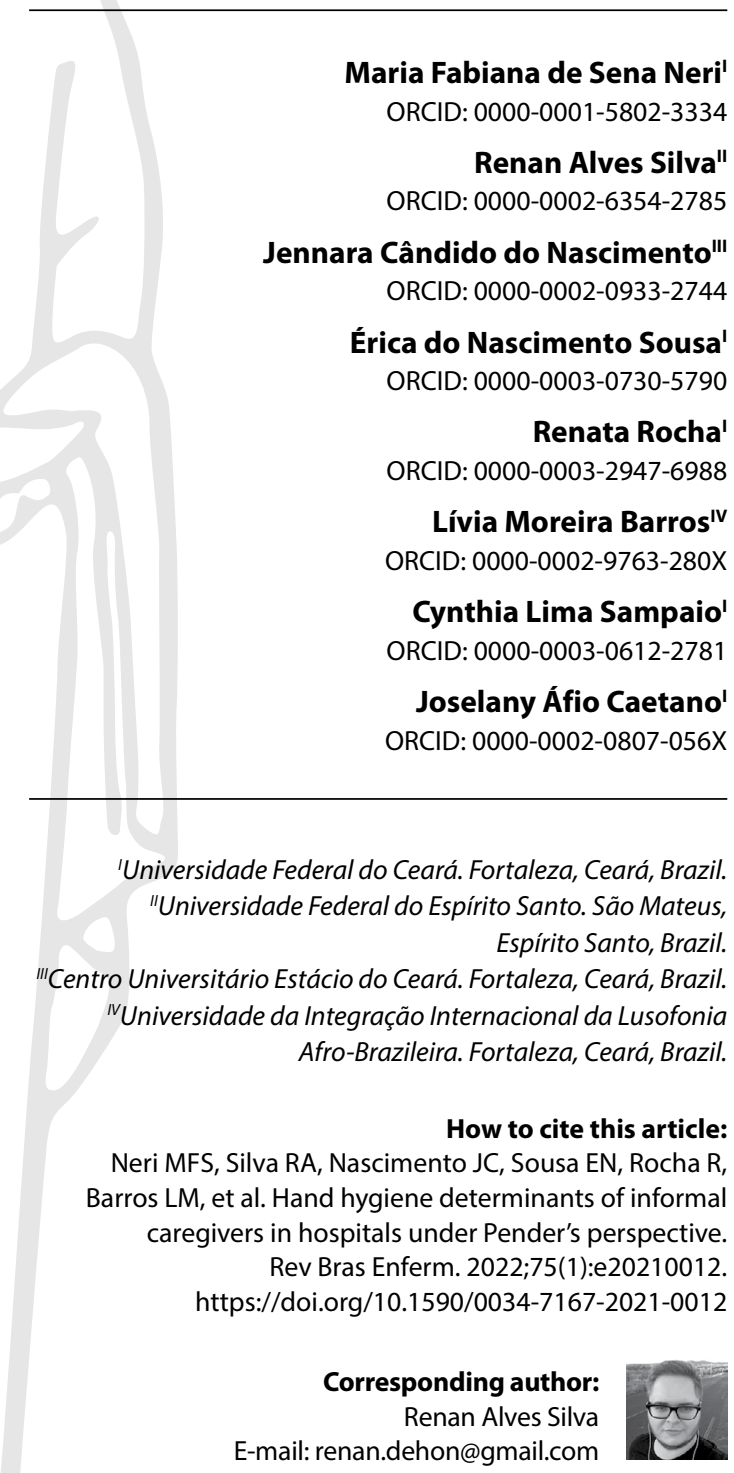

EDITOR IN CHIEF: Antonio José de Almeida Filho ASSOCIATE EDITOR: Carina Dessotte

\begin{abstract}
Objectives: to analyze hand hygiene determinants of informal caregivers in a hospital environment. Methods: qualitative study conducted with 55 caregivers at a university hospital in the Northeast of Brazil. A semi-structured instrument was used, adapted from Nola Pender's Health Promotion Model, from which the deductive categories were derived. Results: the general behavior included hand hygiene before meals and after using the bathroom. Sensitivity to the requirements for hand hygiene was observed, but the barriers and self-efficacy consisted of the availability of soap or alcohol-based hand sanitizers, the lack of knowledge on the importance of and forgetfulness of the practice. The reinforcement on the importance of the practice and being in a contaminated environment were influencers, and commitment, warnings, and training were indispensable. Conclusions: benefits related to protection from infections were seen as positive determinants for hand hygiene adherence. For non-adherence, factors such as lack of sanitizing supplies, ignorance towards the importance of the activity, and forgetfulness stood out.
\end{abstract}

Descriptors: Health Promotion; Caregivers; Patient Safety; Hand Hygiene; Nursing Research.

\section{RESUMO}

Objetivos: analisar os determinantes de higienização das mãos de cuidadores informais em ambiente hospitalar. Métodos: estudo qualitativo realizado em um hospital universitário da Região Nordeste do Brasil, com 55 cuidadores. Utilizou-se de instrumento semiestruturado, adaptado do Modelo de Promoção da Saúde, de Nola Pender, do qual derivaram as categorias dedutivas. Resultados: o comportamento geral incluiu higiene das mãos antes das refeições e após utilizar o banheiro. Observou-se sensibilidade para higienizar as mãos, porém as barreiras e a autoeficácia consistiram na disponibilidade de sabão ou álcool em gel, no desconhecimento acerca da importância e no esquecimento da prática. O reforço da importância da prática e estar em ambiente contaminado foram influenciadores, sendo imprescindíveis compromissos, avisos e treinamentos. Conclusões: identificaram-se determinantes positivos para adesão da higiene das mãos como benefícios relacionados à proteção de infecção. Para não adesão, destacaram-se fatores como ausência de insumos, desconhecimento da importância e esquecimento.

Descritores: Promoção da Saúde; Cuidadores; Segurança do Paciente; Higiene das Mãos; Pesquisa em Enfermagem.

\section{RESUMEN}

Objetivos: analizar determinantes de higienización de manos de cuidadores informales en ambiente hospitalario. Métodos: estudio cualitativo realizado en hospital universitario de Región Nordeste de Brasil, con 55 cuidadores. Utilizado instrumento semiestructurado, adaptado del Modelo de Promoción de la Salud, de Nola Pender, del cual derivaron categorías deductivas. Resultados: conducta general incluyó higiene de manos antes de comidas y después de ir al baño. Observó sensibilidad para higienizar las manos, pero las barreras y la autoeficacia consistieron en la disponibilidad de jabón o alcohol en gel, en el desconocimiento acerca de la importancia y en el olvido de la práctica. Refuerzo de la importancia de la práctica y estar en ambiente contaminado fueron influyentes, siendo imprescindibles compromisos, avisos y entrenamientos. Conclusiones: identificaron determinantes positivos para adhesión de higiene de manos como beneficios relacionados a la protección de infección. Para no adhesión, destacaron factores como ausencia de insumos, desconocimiento de la importancia y olvido. Descriptores: Promoción de la Salud; Cuidadores; Seguridad del Paciente; Higiene de Manos; Investigación en Enfermería.

Submission: 01-09-2021 Approval: 03-16-2021 


\section{INTRODUCTION}

The term "healthcare-associated infections" (HAls) refers to infections that can be acquired as a result of health care, regardless of hospitalization ${ }^{(1)}$. The HAls consist of adverse events present in health services, increasing the costs associated with patient care as well as prolonging hospital stay, morbidity, and mortality (2).

The HAls are associated with the type of assistance provided and can be transmitted by objects or by the hands of health professionals and other people who come into contact with the patient, such as family members, caregivers, and visitors ${ }^{(3)}$. Generally, caregivers and/ or family members are at risk of contracting HAls due to repeated exposure to infectious agents combined with poor hand hygiene and other preventive measures related to disease transmission ${ }^{(4)}$.

Nowadays, informal caregivers have been considered as resources working in favor of the sick person, but not necessarily as the focus of attention, however, they do not have adequate knowledge about standard precautions, specifically regarding hand hygiene $(\mathrm{HH})$, isolation measures, and other items related to patient safety, such as the proper disposal of garbage and the restriction of visits by family members. Therefore, it is essential to intervene in this reality as to share good practices aimed at patient safety, specifically those related to $\mathrm{HH}$.

Noteworthy data related to this problem, a qualitative study conducted in Porto Alegre, state of Rio Grande do Sul (RS), Brazil, with 40 informal caregivers of children hospitalized in pediatric wards, reported deficit in the guidelines on $\mathrm{HH}$ and failures in the hospital environment, such as the absence of sinks in the wards, which favors non-adherence to hand hygiene care ${ }^{(5)}$. Another observational study implemented in Fortaleza, state of Ceará (CE), with 50 caregivers, also identified flaws in the hospital's organizational structure related to the participants' dissatisfaction with the lack of necessary resources for $\mathrm{HH}$, such as paper towels near the sinks ${ }^{(6)}$.

In this context, recognizing the determinants that favor or not $\mathrm{HH}$ on behalf of informal caregivers is relevant to enhance the culture of patient safety in health services, especially in the hospital environment. The identification of risk factors in the daily lives of these caregivers that hinder the practice of hand hygiene can favor the reduction of adverse events, such as HAls, which cause harm to patients. Thus, despite the efforts made to investigate the preventive measures of HAls, there are still many gaps in this area of knowledge, mainly involving the participation of informal caregivers, who are most often a family member.

A theoretical perspective that offers a more comprehensive approach to study the practice of hand hygiene in care is the Health Promotion Model (HPM), by Nola Pender, seldom explored in hospital care actions in $\mathrm{Brazi}^{\left({ }^{(7)}\right.}$. This theoretical model integrates behavioral sciences with nursing theories, seeking to identify the factors that influence healthy behaviors, based on the biopsychosocial context, analyzing three fundamental components: personal characteristics and experiences; feelings and understanding about the health promotion behavior that one aims to achieve; and results of the conduct ${ }^{(7)}$.

Based on the analysis of these three components, it is possible to construct a diagram to be implemented in health promotion actions, in the search for changing inappropriate behavior, holding, at its core, the behaviors to be achieved, as well as the variables: interrelation of individual characteristics and experiences; benefits and barriers to action; self-efficacy; interpersonal and situational influences; commitment to the action plan that allows the individual to maintain the expected health promotion behavior; and the results of HPM implementation ${ }^{(7)}$.

Thus, this model was chosen as it facilitates understanding of the reality of informal caregivers, the determinants for health practice and, specifically for this study, the focus on the hand hygiene of informal caregivers in a hospital environment. Analyzing these determinants may contribute to the safety of inpatients, collaborating to reduce health problems in this population and reinforcing good practices in service.

That said, the question was asked: What are the determinants for informal caregivers' practice of hand hygiene?

\section{OBJECTIVES}

To analyze hand hygiene determinants of informal caregivers in a hospital environment.

\section{METHODS}

\section{Study type and scenario}

Qualitative study, based on Nola Pender's Health Promotion Model, carried out in a large university hospital in the Northeast Region of Brazil, through a focus group, from December 2017 to February 2018. We used the checklist Consolidated Criteria for Reporting Qualitative Research (COREQ) to ensure better validity of methodological aspects. The article originated from the master's thesis entitled "Hand hygiene educational technology with caregivers: based on Nola Pender's Health Promotion Model".

\section{Study population and sample}

The intentional sampling strategy was adopted to choose informal caregivers who had been in the selected hospital environment for more than two weeks. This timeframe was established by considering it necessary to know the routine of the health professionals. Disregarded from the study were informal caregivers who did not leave the ward due to patient dependence, as well as those absent from the sector during the period of data collection.

In this study, "caregiver" was defined as the person who takes on the role of assisting the patient in a situation of total and/or partial dependency from performing daily activities in the hospital environment ${ }^{(5)}$. In general, the participation of caregivers in health institutions is a reality; these are co-participants in the health-disease continuum ${ }^{(6)}$.

\section{Data collection}

The information was collected in three moments: interview, and application of the semi-structured data collection instrument; workshop, with multimodal educational intervention; and post-workshop evaluation.

The interviews were scheduled according to the availability of the caregivers, being recorded and transcribed in full. The 
duration of each was, on average, from eight to ten minutes, having been conducted with the support of a script prepared by the authors, consisting of sociodemographic variables, assessment of barriers, benefits, and recognition of contextual influences in the intention to change targeted $\mathrm{HH}$ behavior.

In addition, direct observation of caregiver $\mathrm{HH}$ frequency was carried out, based on World Health Organization protocols, however, adapted to four moments, according to the caregivers' routine: before and after having contact with the patient; and after touching bodily fluids and surfaces close to the patient.

The educational intervention was carried out through a workshop that addressed topics about health system related infections, $\mathrm{HH}$ moments, application and evaluation of hand washing technique, including video exposure. The study was conducted by three main researchers: a nurse and two previously trained nursing students. It is noteworthy that the effectiveness of this intervention will not be addressed from an experimental analytical logic, since it is not the objective of the present study.

\section{Data handling and analysis}

For data analysis, the thematic analysis technique was used, which allows to classify the content of analysis into themes, which can be interpreted in theoretical dimensions suggested by the material ${ }^{(8)}$, followed by the stages of collection, coding, and grouping. After the transcription, the speeches were preanalyzed, verifying what themes they referred to and, afterwards, they were grouped, establishing categories that contemplated the themes identified later, which were validated by three experts in qualitative studies.

From thereon, discussions were conducted based on the theoretical framework of Nola Pender, seeking to understand the behavior of informal caregivers on the practice of $\mathrm{HH}$; the general behavior adopted; the benefits; the barriers and self-efficacy perceived to perform $\mathrm{HH}$; affectivity related to the activity; and interpersonal and situational influences on the desired behavior.

\section{Ethical aspects}

This study is part of the "Hand hygiene educational technology with caregivers: based on Nola Pender's Health Promotion Model" project, approved by the Research Ethics Committee of the Federal University of Ceará, according to Opinion n².412.806/2017, adhering to recommendations of research involving human beings, according to Resolution No. 466/2012 of the National Health Council. To ensure participants' confidentiality, the caregivers were identified by the letter $C$, followed by Arabic numbers $(C 1, C 2 \ldots)$.

\section{RESULTS}

The sample consisted of 55 informal caregivers, who, in their majority, were female (74\%), with an average age of 37.8 years, mostly between the ages of 26 and 30 years (16\%), of mixed race (45\%), from inland Ceará (48\%), single (48\%), with an average of 10.4 years of education, Catholic (50\%), and homemakers (62\%). Regarding kinship, most participants were daughters (36\%) or spouses (42\%).
The time spent in a hospital environment varied, from three weeks to more than one month, up to three months. Most reported taking turns with other family members and having previous experience in the hospital environment. Still, in this group, regarding their occupations, 28 (50.9\%) were unemployed.

\section{Informal caregivers' previous hand hygiene behavior}

The general $\mathrm{HH}$ behavior adopted by informal caregivers at home included washing hands before meals (89\%) and after using the bathroom (98\%), with the habitual use of liquid soap and water (58\%); and in hospitals, alcohol-based hand sanitizers (22\%). Pertaining the drying of hands, the most cited items were the shared hand towel (46\%), at home; and paper towels (52\%), in hospital settings.

Previous family experiences were perceived as influencing the forming of the hand hygiene habit, especially those related to maternal guidance, at school, and in the work environment.

\section{Informal caregivers' perceptions of benefits and barriers of hand hygiene practice}

The perceived benefits referred to the notions of hygiene and the cultural aspects of relevance of this practice in the elimination of disease, as observed in the statements:

Because we decrease the risk of getting a disease. (C20)

The benefit is because l am protecting myself from infection. And, consequently, protecting my relative. (C24)

Participants reported situations inherent to the act of caring which represent perceived risks that can cause a greater state of alert, such as touching the patient and his belongings, changing the bedding, and interacting with other caregivers and patients.

The perceived barriers consist of perceptions of the difficulties and personal costs to perform hygiene. The main barriers were unavailability of sanitizing supplies, ignorance towards their importance, and forgetfulness.

Here, in the hospital, sometimes there was a lack of soap. (C18)

[...] Sometimes, in some public environments, there is nothing in the bathroom, not even toilet paper. (C08)

Sometimes, the person rushes in from work or any other activity and does not wash correctly. (C13)

As for the lack of knowledge about the importance of hand hygiene, the participants expressed interest in receiving instructions on how to do this properly in the hospital environment and signaled the absence of training.

I think that when nurses are going to attend them, they should encourage caregivers to use alcohol-based sanitizers every time they have an activity with a patient. (C54)

[...] The act of asking if the companion is washing his hands [...] makes him pay attention and put in his mind that he has to clean them because it is really dangerous. So, with this, the professional is influencing the habit of washing hands. (C05) 
The perceived self-efficacy was expressed by encouraging this behavior during contact with patients, as well as the responsibility that this practice represents:

If I don't have any supplies to wash them, I'll go after it. (C17)

In the caregivers' women's bathroom, there is no soap nor paper towel. I take some paper and a little soap from the infirmary. (C48)

Most said they had the skills to perform hand hygiene:

[...] I always take the time to wash my hands. (C20)

[...] My sister is always reminding me; l am getting better at it. (C42)

Regarding the feelings related to the behavior of $\mathrm{HH}$, it was identified among the participants that it was necessary and desirable to carry out $\mathrm{HH}$ even when experiencing a scarcity of sanitization products. Many expressed a feeling of obligation of performing $\mathrm{HH}$ and cited critical moments in which this action should be performed, such as: after using the bathroom, upon entering the infirmary, after being in contact with the patient and before meals.

[...] I always have to keep my hands clean; she has low immunity. So, any bacteria can harm her. (C29)

It is essential to wash your hands before eating, in hospitals and when leaving the bathroom; I confess that I forget sometimes. (C26)

It was noted that self-efficacy was not associated with the appropriate technique or frequency.

Interpersonal influences, on the other hand, include social norms, social support, and modeling functions. The social norms associated with this practice were identified as correct behaviors:

My mother, for example, when she prepares food, she washes her hands. (C16)

Mom asks if our hands are clean before we pick up a cup. (C25)

When investigating situational influences in $\mathrm{HH}$ behavior, places were mentioned where people can be found who practice $\mathrm{HH}$; respondents cited restaurants, hospitals, and schools:

In the sink at the entrance to the office and alcohol-based hand sanitizer outside the infirmary. (C09)

At my work, in the kitchen, they wash and put alcohol-based hand sanitizer. (C39)

From what I know, in hospitals and schools. (C21)

Respondents were encouraged to exemplify strategies for achieving hand hygiene behavior, with emphasis on commitment.

There are four in the infirmary, I and another person use it, but there are others who don't. I think it would be good, from time to time, for you guys to go from room to room and give guidance, including with the use of educational material, professional warnings, and ensuring availability of supplies. (C55)

Other strategies to reinforce hand washing behavior are the distribution of leaflets, guidance from health professionals, warnings, training, lectures, and ensuring availability of supplies, in specific stations, such as sinks in the wards, corridors, and cafeteria.

\section{Informal caregivers' commitment to adhere to the hand hygiene action plan}

With the purpose of contributing to the achievement and upkeep of a $\mathrm{HH}$ health promotion behavior, strategies were developed to enable the overcoming of perceived barriers that relate to action, negative interpersonal and situational influences, as well as emerging competitive demands.

To meet the established goal, an educational workshop was held in order to facilitate the understanding of caregivers about $\mathrm{HAls}$, the importance of $\mathrm{HH}$, and about their role in preventing infections, as noted:

If I don't maintain hand hygiene, I can transmit bacteria to the patient. (C3)

Then, the video "Higienização das Mãos do Hospital Mãe de Deus" [Hand Hygiene at Mãe de Deus Hospital] was shown, in order to raise awareness about behavior, benefits, and barriers to implementation. The importance of $\mathrm{HH}$ was reinforced as a precept to be followed in the hospital environment, linked to the safety of the patient, professionals, caregivers, and the community.

Following, the $\mathrm{HH}$ sanitizing supply was presented and the technique was shown step by step, reinforcing the areas often forgotten when washing hands (thumbs, fingertips, and between fingers). In the execution of the $\mathrm{HH}$ technique, the least performed steps were: "soaping the palm of the right hand and rubbing it against the back of the left hand, interlacing the fingers and vice versa" and "rubbing the digital pulps and nails of the left hand against the palm of the right hand, cupped closed, making a circular movement and vice versa". The mentioned areas were little affected by the rubbing of alcohol-based sanitizers with fluorescent paint, which made it easier for informal caregivers to visualize the flaws in the realization of $\mathrm{HH}$.

\section{Immediate requirements and preferences for performing hand hygiene}

The difficulties that compromised the performance of the $\mathrm{HH}$ technique by informal caregivers were perceived as ignorance of the technique itself and reduced engagement of professionals in the continuous encouragement of this practice, in the daily routine of patient care.

Professionals were supposed to be guiding caregivers on how to wash their hands and explain the glove after you used it [...] because after you touch the patient and get it dirty, you should throw it away and then wash your hands. (C01) 


\section{Nola Pender's Health Promotion Model diagram, with deter-} minants associated with informal caregivers' hand hygiene

Aiming to operationalize the stages of planning, intervention, and evaluation of health promotion actions with regard to this practice, the diagram was elaborated based on the onscreen theoretical model. Thus, it appears that this diagram is a graphic and visual presentation, composed of links, arrows, and rectangles that describe a logical sequence of the relationships and the types of interactions between the general behavior to be adopted, benefits, barriers, and perceived self-efficacy to perform $\mathrm{HH}$, affection related to the activity, and interpersonal and situational influences on the health promotion behavior - in this case, the awareness of the need for $\mathrm{HH}$.

\section{DISCUSSION}

As mentioned, the studied group was composed predominantly of women, and this corroborates to what has been described in literature about the supremacy of the female gender in the role of caregiver ${ }^{(9)}$. As evidence, a study reported that older people seem to be more aware of the risk of infection in hospitals than young people; and, in this configuration, women are more aware than men ${ }^{(10)}$. Still, a predictive correlational study revealed that the hand washing habit increases in older age groups $(p=0.001)$, in women $(p=0.001)$, in urban dwellers $(p=0.001)$ and with the increase in education levels $(p=0.001)^{(11)}$.

Associated with the profile of caregivers, evidence of the influence of domestic habits in this population imbues patient safety actions, as habits acquired in the family promote greater chances of enduring, such as hand hygiene during hospital follow-up ${ }^{(12)}$. The variables collected showed that the caregivers' behavior included habits acquired in family environments (home, school, and work) or even in the experience of caring. It is noted that habits acquired in the family are reproduced in other contexts, such as during hospitals follow-ups ${ }^{(12)}$.

It was observed that $\mathrm{HH}$ occurs in hospital services according to the recommendations of the Health Surveillance Agency, considering the propitious moments of contact with the patient and the patient's needs ${ }^{(3)}$. When assessing the compliance of this practice in public interaction, the critical points of hygiene are: food preparation and trips to the bathroom, before touching a patient; after procedures that can lead to exposure of bodily fluids; and after touching objects in the care area ${ }^{(3)}$.

The benefits of this perceived behavior are recognized as cultural representations of the positive consequences of the adopted conduct, being essential for the prevention of infections, which mainly result from the contamination of the hands of health professionals through direct contact with colonized or infected patients

Figure 1 - Diagram of the Theoretical Model of Health Promotion, by Nola Pender, adapted to promote hand hygiene in caregivers, Fortaleza, Ceará, Brazil, 2018 
and the contact with the environment or surfaces close to the patient. It is noteworthy that the hand hygiene habit of the team, patients, and caregivers can significantly reduce the transmission of microorganisms, especially resistant ones ${ }^{(1)}$.

Among the perceived barriers, there were difficulties and personal costs, such as unavailability of sanitizing supplies, ignorance towards this practice in the hospital environment, and forgetfulness. Studies show the need for hand washing supplies and consider that hygiene with soap and water is effective in removing pathogens from the surface of the hands ${ }^{(13-14)}$, as well as the protective effect of using alcohol-based sanitizers, which promotes the inactivation of a wide range of viruses and bacteria ${ }^{(15)}$.

Regarding the "forgetting to wash hands" factor, it is hypothesized that a regular daily routine facilitates the memory of performing $\mathrm{HH}$. It should be added that frequent task interruptions were associated with little indication of hand washing in studies that investigated the socially desirable and additional response factors for the bias between self-reported and observed hand washing behavior ${ }^{(16-17)}$.

Informal caregivers were encouraged to perform hand hygiene and justified the practice of trying to acquire supplies when those were lacking as self-efficacy. However, even when motivated, some factors can be barriers, such as poor hospital infrastructure, including lack of water and hand washing locations ${ }^{(4,6)}$.

With regard to interpersonal influences, it was found that social norms put indirect pressure on caregivers to commit themselves to carrying out the practice properly. Qualitative and quantitative assessments of hand washing show that perceptions that others, when practicing recommended behaviors, influence the adoption of best hand washing practices ${ }^{(18-19)}$.

The situational influences for the aforementioned behaviors were places such as restaurants, hospitals, and schools, in which they performed the practice of $\mathrm{HH}$, but which do not always have the sanitizing supplies. Informal caregivers can often wash their hands with just water, but water alone removes less pathogens than soap and alcohol; and washing hands with water alone is less effective in preventing diarrhea and other infectious diseases than washing them with soap ${ }^{(20)}$.

Caregivers associated hand washing with infection prevention; and some, from the experience of accompanying a patient in isolation ${ }^{(21)}$, perceived the isolation measures with uncertainty, fear, anguish, and anger, but demonstrated intentions to perform $\mathrm{HH}$, as well as questioning the effectiveness of this practice by health professionals as one of the ways to maintain patient safety.

It was noted that the video exposure was more of an educational strategy that provided information to caregivers about the importance of $\mathrm{HH}$ and how this action could contribute to the reduction of HAls ${ }^{(22-23)}$, improving the level of patient safety. The proper technique is decisive for effective decontamination of the hands ${ }^{(15)}$. This requires interventions that, in addition to promoting frequent hand washing at key moments, also provide the appropriate technique for this purpose ${ }^{(24)}$.

Based on the results of this study, it is considered that the multimodal interventions used were sufficient to produce an increase in adequate hand hygiene, regarding the circumstances that influence this behavior ${ }^{(22-24)}$. It is inferred, therefore, that the Health Promotion Model, by Nola Pender, is a useful tool to help nurses understand the factors that influence informal caregivers' $\mathrm{HH}$ practice.

\section{Study limitations}

Perceived limitations were found in a convenience-based sample and in a single data collection center, which may hinder the generalization of results to other contexts. The aforementioned findings and the construction of a diagram must be viewed with caution, as the philosophy and vision of the institution are preponderant aspects in the scenario of action of the desired behavior change within the hospital scenario. Thus, it is understood that the results shown may be satisfactory for hospitals that promote health and that defend the culture of patient safety.

\section{Contributions to health and the field of Nursing}

Knowing and analyzing caregivers $\mathrm{HH}$ determinants in a hospital environment can favor both the empowerment to adopt safe practices and the development of strategies that can increase the understanding of the risks of infection in the hospital environment and provide opportunities for their participation in the care process. In addition to these aspects, the caregiver's participation in care, in a way, contributes to the multiprofessional team. Still, the need for improving availability of infrastructure and supplies that favor the practice of $\mathrm{HH}$ was noted.

At the end of the research, there was positive feedback from caregivers regarding the meetings and health professionals, which resulted in a work group with weekly development of health education activities, with caregivers as the target audience.

\section{FINAL CONSIDERATIONS}

Based on the reports of informal caregivers, benefits related to protection from infections were seen as positive determinants for $\mathrm{HH}$ adherence. For non-adherence, factors such as lack of supplies, ignorance towards the importance of the activity, and forgetfulness stand out.

With the elaboration of the diagram of the determinants of hand hygiene of hospital caregivers, based on Nola Pender's Theoretical Model of Health Promotion, it was found that the commitment to the action plan for hand hygiene behavior implies: cognitive processes to carry out this behavior in the hospital, in moments of patient care, influenced by the benefits of preventing infections; previous behavior, in accordance with hand hygiene practice; definition of objectives for the desired behavior; and identification of definitive strategies to induce, implement, and reinforce behavior.

Thus, the constructed diagram is valid to guide the planning and implementation of actions in the evaluated context, which allows better results on $\mathrm{HH}$ adherence and other standard precautions, contributing to patient safety in the hospital environment. 


\section{REFERENCES}

1. Ferreira LL, Azevedo LMN, Salvador PTCO, Morais SHM, Paiva RM, Santos VEP. nursing care in healthcare-associated infections: a scoping review. Rev Bras Enferm. 2019;72(2):498-505. https://doi.org/10.1590/0034-7167-2018-0418

2. Oliveira HM, Silva CPR, Lacerda RA. Policies for control and prevention of infections related to healthcare assistance in Brazil: a conceptual analysis. Rev Esc Enferm USP. 2016;50(3):502-8. https://doi.org/10.1590/S0080-623420160000400018

3. Agência Nacional de Vigilância Sanitária (ANVISA). Pacientes pela segurança do paciente em serviços de saúde: Como posso contribuir para aumentara segurança do paciente? orientações aos pacientes, familiares e acompanhantes [Internet]. Brasília: Anvisa; 2017[cited 2020 Apr 20]. Available from: http://portal.anvisa.gov.br/documents/33852/3507912/Como+posso+contribuir+para+aumentar+a+segurança+do+p aciente/52efbd76-b692-4b0e-8b70-6567e532a716

4. Islam MS, Luby SP, Sultana R, Rimi NA, Zaman RU, Uddin M, et al. Family caregivers in public tertiary care hospitals in Bangladesh: risks and opportunities for infection control. Am J Infect Control. 2014;42(3):305-10. https://doi.org/10.1016/j.ajic.2013.09.012

5. Hoffmann LM, Wegner W, Biasibetti C, Peres MÁ, Gerhardt LM, Breigeiron MK. Patient safety incidents identified by the caregivers of hospitalized children. Rev Bras Enferm. 2019;72(3):707-14. https://doi.org/10.1590/0034-7167-2018-0484

6. Neri MFS, Galindo Neto NM, Sampaio CL, Medina LAC, Barros LM, Caetano JÁ. Behavior on hand hygiene practices of companions in inpatient wards. Rev Rene. 2019;20:e41015. https://doi.org/10.15253/2175-6783.20192041015

7. Pender NJ, Murdaugh CL, Parsons MA. Health Promotion in Nursing Practice. 7. ed. United States of America: Pearson Education; 2015.

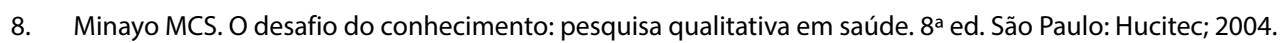

9. Casado-Mejía R, Ruiz-Arias E. Influence of gender and care strategy in family caregivers' strain: a cross-sectional study. J Nurs Scholarsh. 2016;48(6):587-597. https://doi.org/110.1111/jnu.12256

10. Fóa C, Tura GA, Camelli C, Silingardi R, Malavolti M, Kuenzer E, et al. Hand hygiene in health care settings: the citizens' point of view. Acta Biomed. 2017;88(1S):40-53. https://doi.org/10.23750/abm.v88i1 -S.6283.

11. Tüzün H, Karakaya K, Deniz EB. Turkey Handwashing Survey: suggestion for taking the ecological model into better consideration. Environ Health Prev Med. 2015;20:325-331 https://doi.org/10.1007/s12199-015-0470-6

12. Barker A, Sethi A, Shulkin E, Caniza R, Zerbel S, Safdar N. Patients' hand hygiene at home predicts their hand hygiene practices in the hospital. Infect Control Hosp Epidemiol. 2014;35(5):585-588. https://doi.org/10.1086/675826

13. Haverstick S, Goodrich C, Freeman R, James S, Kullar R, Ahrens M. Patients' hand washing and reducing hospital-acquired infection. Crit Care Nurse. 2017;37(3):e1-e8. https://doi.org/10.4037/ccn2017694

14. Heckel M, Sturm A, Herbst FA, Ostgathe C, Stiel S. Effects of methicillin-resistant staphylococcus aureus/multiresistant gram-negative bacteria colonization or infection and isolation measures in end of life on family caregivers: results of a qualitative study. J Palliat Med. 2017;20(3):273-81. https://doi.org/10.1089/jpm.2016.0301

15. Friedrich MND, Kappler A, Mosler H. Enhancing handwashing frequency and technique of primary caregivers in Harare, Zimbabwe: a cluster-randomized controlled trial using behavioral and microbial outcomes. Soc Sci Med. 2018;196:66-76. https://doi.org/10.1016/j. socscimed.2017.10.025

16. Contzen N, Pasquale S, Mosler H. Over-reporting in handwashing selfreports: potential explanatory factors and alternative measurements. Plos One. 2015;10(8):1-22. https://doi.org/10.1371/journal.pone.0136445

17. Srigley JA, Cho SM, O'Neill C, Bialachowski A, Ali RA, Lee C, et al. Hand hygiene knowledge, attitudes, and practices among hospital inpatients: a descriptive study. Americ J Infect Control. 2019:1-4. https://doi.org/10.1016/j.ajic.2019.11.020

18. Arbianingsih HN, Utario Y, Rustina Y, Krianto T, Ayubi D. Arbi Care application increases preschool children's hand-washing self-efficacy among preschool children. Enferm Clín. 2018;28(S1):27-30. https://doi.org/10.1016/s1130-8621(18)30031-7

19. Nizame FA, Unicomb L, Sanghvi T, Roy S, Nuruzzaman M, Ghosh PK, et al. Handwashing before food preparation and child feeding: a missed opportunity for hygiene promotion. Am J Trop Med Hyg. 2013;89(6):1179-85. https://doi.org/10.4269/ajtmh.13-0434

20. Amin N, Sagerman DD, Nizame FA, Das KK, Nuruzzaman M, Yu J, et al. Effects of complexity of handwashing instructions on handwashing procedure replication in low-income urban slums in Bangladesh: a randomized non-inferiority field trial. J Water, Sanitat Hygiene Developm. 2019;9(3), 416-428. https://doi.org/10.2166/washdev.2019.131

21. Okada J, Yamamizu Y, Fukai K. Effectiveness of hand hygiene depends on the patient's health condition and care environment. Japan J Nurs Sci. 2016;13(4):413-23. https://doi.org/10.1111/jjns.12122

22. Karadag $E$. The effect of a self-management program on hand-washing/mask-wearing behaviours and self-efficacy level in peritoneal dialysis patients: a pilot study. J Renal Care. 2019;45(2):93-101. https://doi.org/10.1111/jorc.12270

23. Gould DJ, Moralejo D, Drey N, Chudleigh JH, Taljaard M. Interventions to improve hand hygiene compliance in patient care. Cochrane Database System Rev. 2017:CD005186. https://doi.org/10.1002/14651858.CD005186.pub4

24. Migliara G, Di Paolo C, Barbato D, Baccolini V, Salerno C, Nardi A,et al. Multimodal surveillance of healthcare associated infections in an intensive care unit of a large teaching hospital. Ann lg. 2019;31(5):399-413. https://doi.org/10.7416/ai.2019.2302 